\title{
PEMAHAMAN GENRE DALAM KETRAMPILAN MEMBACA PADA PEMBELAJARAN BAHASA INGGRIS PROFESI PADA MAHASISWA PROGRAM STUDI KEPARIWISATAAN, STIPAR TRIATMA JAYA, BALI
}

\author{
Ni Nym. Nidya Trianingrum, S.Pd.M.Pd. ${ }^{1}$, \\ Ni Putu Yunik Anggreni, S.S.M.Hum² \\ Sekolah Tinggi Ilmu Pariwisata Triatma Jaya \\ nidyatrianingrum123@gmail.com¹, yunikangreni73@gmail.com²
}

\begin{abstract}
Abstrak
Penelitian ini menerapkan pendekatan genre dalam pembelajaran keterampilan membaca pemahaman teks berbahasa Inggris. Tujuan penelitian ini adalah untuk meningkatkan keterampilan membaca pada mahasiswa Kepariwisataan. Subyek penelitian adalah mahasiswa Manajemen Kepariwisataan (MPW) Diploma III, semester 4, Sekolah Tinggi Pariwisata (STIPAR) Triatma Jaya, Badung, Bali, tahun ajaran 2017/2018 yang berjumlah 16 orang. Penelitian yang tergolong penelitian eksperimen ini dilakukan dengan memberikan tes terikat atau multiple choise sebanyak 20 soal. Tes tahap ini untuk menentukan pemahaman mahasiswa terhadap 5 jenis genre teks ( report, recount, advertisement, procedure, dan descriptive). Pembelajaran dalam 2 kali pertemuan disajikan sebagai tahap pemantapan pada pemahaman kelima jenis teks tersebut. Tes tahap kedua dilaksanakan dalam bentuk tes menulis karangan bebas dalam kelima kategori genre teks yang disajikan pada pembelajaran keterampilan berbicara. Data dijaring melalui 2 kali tahapan tes dan disajikan dalam bentuk table untuk mendukung paparan descriptive. Tingkat kemampuan mahasiswa dalam mengidentifikasikan genre dari masing-masing teks berbeda-beda yaitu genre recount text $93.75 \%$, advertisement text $87.50 \%$, descriptive text $68.75 \%$, procedure text $43.75 \%$, dan report text $56.25 \%$. Pemerolehan score prosentasi dari setiap genre tersebut mengidentifikasikan bahwa mahasiswa sudah mampu memahami genre recount, descriptive, report dan advertisement. Hal ini dapat dibuktikan dengan prosentase pemerolehan sebanyak $50 \% \mathrm{~s} / \mathrm{d}$ 90\%. Sedangkan mahasiswa belum mampu dalam mengidentifikasikan genre procedures text, hal ini dibuktikan pada pemerolehan score $43.75 \%$. Jenis genre teks yang lebih mudah dipahami dan ditulis oleh mahasiswa MPW STIPAR Triatma Jaya adalah descriptive text (100\%), advertisement text (93.75\%), dan recount text (87.50). Peningkatan pemahaman descriptive text dan advertisement text disebabkan oleh penyajian pembelajaran tentang pemahaman genre teks melalui keterampilan membaca pemahaman (reading comprehension). Peningkatan keterampilan membaca pemahaman berhubungan dengan pembelajaran keterampilan menulis.
\end{abstract}

Kata kunci: reading comprehension skill, tourism management students

\section{PENDAHULUAN}

Membaca merupakan sebuah kegiatan rekognisi, yaitu sebuah kegiatan dalam pengenalan bentuk yang berkaitan dengan makna yang tersirat, serta pemahaman yang keseluruhannya masih harus melalui tahap-tahap kegiatan tertentu (Aminuudin, 2010 :15). Membaca merupakan sebuah keterampilan reseptif bahasa tulis. Keterampilan membaca dapat dikembangkan secara tersendiri, terpisah dari keterampilan mendengar dan berbicara. Tetapi, pada masyarakat yang memiliki tradisi literasi yang telah berkembang, seringkali keterampilan membaca dikembangkan secara terintregrasi dengan keterampilan menyimak, menulis dan berbicara. Keterampilan-keterampilan mikro yang berhubungan dengan keterampilan membaca yang harus dimiliki oleh pembicara adalah (1) mengenal sistem tulisan yang digunakan, (2) mengenal kosakata, (3) menentukan kata-kata kunci 
yang mengindentifikasikan topik dan gagasan utama, (4) menentukan makna kata-kata, termasuk kosakata split, dari konteks tertulis, dan (5) mengenal kelas kata gramatikal, kata benda, kata dan sifat.

Dalam membaca, unsur kebahasaan merupakan aspek penting yang sangat perlu dicermati, disamping isi pesan yang hendak disampaikan yang merupakan inti dari hakikatnya sebagai bentuk penggunaan bahasa yang aktif produktif dalam keterampilan membaca. Diperlukan teori dan pendekatan (approach) untuk mempermudah pembelajaran keterampilan membaca khususnya keterampilan membaca pemahaman (reading comprehension) seperti memahami teks baik secara lisan maupun tertulis dalam berbagai konteks dan beragam peruntukan. Teori tersebut merupakan teori linguistik dan tata bahasa. Dalam menggambarkan bahasa dan penggunaan yang sebenarnya serta berfokus pada teks dan konteksnya diperlukan tatabahasa.

Membaca dalam hati dapat diklasifikasikan menjadi (1) membaca ektensif yaitu proses membaca yang dilakukan secara luas, bahan bacaan yang digunakan bermacam-macam dan waktu yang digunakan singkat dan cepat. (2) Membaca intensif adalah membaca bacaan secara teliti dan seksama dengan tujuan memahami secara rinci. Membaca intensif merupakan salah satu upaya untuk menumbuhkan dan mengasah kemampuan membaca secara kritis. Pemahaman terhadap bacaan terjadi melalui proses penjodohan atau interaksi antara pengetahuan dalam skemata pembaca dengan konsep atau pengertian atau fakta yang terdapat dalam bacaan. Pemahaman terhadap suatu bacaan tidak hanya tergantung pada apa yang terdapat dalam bacaan saja, melainkan juga bergantung pada pengetahuan sebelumnya yang telah dimiliki pembaca. Dalam proses seperti inilah pembaca secara aktif membangun pemahamannya terhadap bacaan.

Salah satu pendekatan yang digunakan untuk mengajarkan keterampilan membaca adalah dengan pendekatan genre (genre approach). Pendekatan genre ini sangat tepat digunakan khusussnya bagi mahasiswa yang belajar bahasa Inggris sebagai tujuan khusus (English for specific Purpos ) dan juga berguna bagi mahasiswa secara umum. Perhatian akan genre (ragam teks) secara signifikan meningkat baik untuk pengajaran bahasa pertama maupun bahasa asing. Dan dalam genre, bahasa dipandang sebagai sumber untuk membentuk sebuah makna.

Pengajaran genre sangat penting diperhatikan khususnya dalam mempersiapkan mahasiswa untuk memahami teks yang berhubungan dengan berbagai jenis genre dalam bukubuku pariwisata pada Program Studi MPW, Diploma III, STPAR Triatma Jaya. Sebuah teks bisa merupakan gabungan beragam genre, dan bisa pula cenderung memfokuskan pada genre tertentu. Genre lebih ditentukan oleh peruntukan teks. Genre muncul dalam interaksi sosial untuk memenuhi tujuan-tujuan hubungan sosial manusia. Kebutuhan genre yang tersaji di kampus akan terpilih lewat tujuan dari program studi yang ditempuh. Genre menggambarkan suatu potensi dimana kreatifitas individu tidak hanya dimungkinkan tetapi juga untuk dikembangkan. Para mahasiswa diajarkan fitur-fitur genre dan kebahasaan untuk membicarakan tentang bahasa dalam konteks belajar bagaimana fitur-fitur ini berkontribusi terhadap makna teks yang sedang dibaca atau ditulis.

Keterampilan membaca sangat berhubungan dengan keterampilan menulis, berbicara dan menyimak. Keterampilan membaca, menulis dan berbicara yang baik dan efektif sangat dibutuhkan oleh mahasiswa MPW STIPAR Triatma Jaya. Tanpa keterampilan tersebut, sangat sulit bagi mahasiswa 
untuk menguasai mata kuliah keterampilan (MKK) yang harus ditempuh selama masa studi mereka. Penguasaan MKK ini pula sangat penting bagi mahasiswa dalam mendapatkan kesempatan mengikuti praktik kerja industri, lulus uji kompetensi dalam okupasi penanganan dan kepemanduan wisata bahkan tujuan terpenting mahasiswa dalam berkompetisi mendapatkan pekerjaan di dunia industri pariwisata di Bali khususnya, bahkan di dunia internasional pada umumnya.

Kemampuan mahasiswa dalam menguasai MKK sangat terkait dengan MK Bahasa Inggris Profesi. Penguasaan MK Bahasa Inggris Profesi (BIP) saling mendukung dengan MKK yang lain. Tanpa kemampuan yang baik dalam penguasaan MK BIP akan mengakibatkan kesultan bagi mahasiswa dalam penguasaan MKK yang disajikan. Penguasaan MKK juga sangat mendukung kemampuan mahasiswa dalam penguasaan MK BIP.

Pembelajaran BIP yang

berhubungan dengan penguasaan MKK Penanganan Kepemanduan Wisata dan Travel Koresponden adalah keterampilan mahasiswa dalam menjelaskan paket tour yang ditawarkan kepada pelanggan. Keterampilan mahasiswa dalam menguasai dan memahami paket tour ini sangat berhubungan dengan kemampuan membaca yang baik dan efektif. Berdasarkan masalah tersebut dipandang perlu menerapkan sebuah pendekatan dalam pemahaman teks dalam bahasa Inggris melalui pendekatan pemahaman genre.

Bertitik tolak dari uraian diatas dan studi pustaka yang berkaitan dengan kajian ini maka yang akan dijadikan permasalahan dalam tulisan ini adalah: (1) Bagaimanakah kemampuan mahasiswa MPW Diploma III semester IV, STIPAR Triatma Jaya, Badung, Bali dalam mengidentifikasi genre dalam beberapa teks tulis ? (2) Apakah jenis genre teks yang paling mudah dipahami dan ditulis oleh mahasiswa MPW Diploma III,
Semester 4, STIPAR Triatma Jaya Badung, Bali?

\section{METODE PENELITIAN}

Penelitian ini merupakan penelitian deskriptif kualitatif yaitu penelitian tentang data yang dikumpulkan dan dinyatakan dalam bentuk kata-kata dan disusun dalam kalimat. Metode ini digunakan untuk mengumpulkan data dan menganalisis data dengan jenis atau metode yang berbeda. Secara kualitatif peneliti akan melakukan survei deskriptif seperti tes kemampuan berbahasa tepatnya kemampuan membaca pemahaman teks. Dengan tes kemampuan membaca pemahaman, dapat diperoleh informasi tentang tingkat kemampuan memahami genre dari sebuah teks pada suatu tahap tertentu.

Peneliti menerapkan proficiency test, yaitu test yang bertujuan untuk menilai kemampuan mahasiswa dalam menerapkan apa yang telah dipelajari ke dalam suasana yang sebenarnya (Harrison, 1989). Tes pertama yang dilakukan adalah objective test. Tes ini berjumlah 20 buah. Surat-Surat Bisnis Berbahasa Inggris yang ditulis oleh Rina Adriani.dan English for tourism yang ditulis oleh Bambang Udoyono. Tes yang kedua adalah tes karangan bebas dimana mahasiswa diberikan kebebasan dalam memilih jenis genre text yang akan ditulis dalam waktu 30 menit.

Penelitian ini dilakukan pada Mahasiswa MPW di STIPAR Triatma Jaya, yang berlokasi di Jalan Kubu Gunung, Tegal Jaya, Dalung, Kuta Utara. Mahasiswa MPW yang menjadi populasi penelitian ini berada pada semester 4 yang berjumlah 16 orang dan sedang menempuh MK BIP3 dan MKK Teknik memandu Wisata dan Travel koresponden Teknik analisis data dengan langkah-langkah mentabulasi data tes pilihan ganda (multiple choice), dan tes bebas dengan melihat struktur skematika (schematic structure) dan unsur kebahasaan (lexicogrammatical) tertentu. 
Misalnya struktur skematika dari report text adalah sebagai (1) general classification: berisi gambaran umum mengenai suatu kejadian dan (2) Description: berisi deskripsi dari kejadian yang ingin disampaikan. Unsur kebahasaannya berfokus pada individual participant, material process, verbal process, time connective and conjunction, dan past tense, (2) menghitung persentase kemampuan mengindentifikasi setiap jenis genre, menggunakan struktur skematika dan unsur kebahasaan, Genre merupakan konteks budaya yang khusus dan berorientasi pada tujuan yang khusus. Tujuan khusus yang harus dijelaskan dengan langkahlangkah atau struktur skematis proses sosial yang beraneka ragam tergantung pada kegiatan yang memiliki tujuan dalam budaya tertentu dan menggunakan ciri-ciri bahasa yang khusus. Genre merupakan bentuk actual teks tertentu yang masuk dalam pembahasan konteks budaya, yaitu struktur skematik. Dengan demikian, dapat disimpulkan bahwa yang dimaksud genre adaah jenis teks (Sinar, 2003). Setiap jenis genre mempunyai ciri dan struktur tersendiri. Struktur genre disebut struktur skematik yaitu pola keseluruhan dan keteraturan di dalam sebuah genre (Martin, 1983). Struktur skematik genre biasanya bervariasi, tetapi secara umum mempunyai pendahuluan,pertengahan dan penutup.

Genre report adalah suatu teks yang mengandung deskripsi objektif yang faktual tentang kejadian dan objek yang berbentuk laporan (Martin, 1983). Wacana laporan berisikan ilustrasi tentang hal-hal yang umum yang dibuat atas fakta-fakta dan juga bersumber dari pengalaman empiris yang diperoleh. Genre laporan lebih bersifat umum. Seperti halnya genre prosedur, genre laporan juga menggeneralisasi pengalaman yang khusus dan merupakan tulisan faktual. Hanya saja genre laporan berfungsi melaporkan fakta dan memfokuskan kepada seperti apa bentuk, ciri suatu benda, atau makhluk.

Martin, 1983 menyatakan bahwa genre deskripsi memusatkan perhatian pada penelitian kelas benda. Genre ini merupakan suatu penjelasan tentang individu atau sesuatu benda yang mempunyai karakteristik tertentu atau tentang bagaimana ciri suatu benda atau individu. Genre ini memiliki sifat yang sama dengan genre laporan, yaitu samasama menulis tentang fakta. Tulisan faktual mendeskripsikan dunia di sekitar manusia. Genre ini memusatkan perhatian pada bagaimana sesuatu terjadi dan seperti apa bentuk, ciri suatu benda atau makhluk.

Genre prosedur adalah suatu teks yang dibangun atas kejadian yang beruntun tentang bagaimana sesuatu terjadi secara bertahap, mempunyai ciri umum dan langkah, memakai bahasa instruksi dan bahasa direktif (Martin, 1983). Teks yang bersifat prosedur menggeneralisasi pengalaman yang khusus. Genre ini merupakan tulisan faktual yang berfungsi menuliskan tata cara membuat atau melakukan sesuatu, tentang bagaimana langkah-langkah suatu kejadian atau tindakan terjadi.

Bahasa adalah fungsional dan fungsi bahasa membuat arti atau makna. Berdasarkan teori Linguistik Fungsional Sistemik, karena banyaknya fungsi bahasa, LFS memakai istilah metafungsi yang mencakup fungsi ideasional, fungsi interpersonal, dan fungsi tekstual. Penelitian ini menggunakan fungsi eksperensial untuk mengetahui pemarkah verba pada data. Manusia hidup untuk merealisasikan pengalamannya, yaitu pengalaman bukan linguistik dapat menjadi pengalaman linguistik. Kenyataan dalam kehidupan manusia atau kejadian sehari-hari adalah pengalaman bukan linguistik yang direalisasikan ke dalam pengalaman linguistik yang terdiri atas tiga unsur, yaitu participant, process, dan circumstance. 
Dalam makna pengalaman kegiatan atau aktivitas yang terjadi dalam klausa disebut proses, yaitu sebagai inti dari satu pengalaman. Istilah proses (process) terwujudkan oleh bentuk kata kerja (verb) dalam suatu kalimat. Melalui makna pengalaman ini manusia menghasilkan verba-verba yang direalisasikan melalui enam jenis proses yang menentukan jenis pengalaman itu. Halliday (2004) membagi jenis proses menjadi tujuh kategori yaitu proses material (material), mental (menta), proses tingkah laku (behavioural), proses proses verbal (verbal), proses relasional (relational), proses wujud (existential), dan proses meteorologi (meteorological).

\section{HASIL DAN PEMBAHASAN}

Pembelajaran BIP pada mahasiswa MPW diploma III, STIPAR Triatma Jaya adalah proses pembelajaran Bahasa Inggris berdasarkan fungsi dan dimana bahasa Inggris itu digunakan ( language use). Pendekatan pembelajaran yang diterapkan adalah pendekatan pemahaman genre. Program Studi Kepariwisataan, konsentrasi MPW adalah merupakan sebuah konsentrasi yang terdapat dalam Program Studi Kepariwisataan yang mempelajari menajemen sebuah travel agent, seperti membuat perencanaan dan penjualan paket-paket tour, strategi pengembangan sebuah objek wisata, sistim keamanan dalam perjalanan wisata, manajemen pemasaran, manajemen keuangan, travel koresponden, ticketing, teknik memandu wisata, BIP dan bahasa Asing Pilihan.

Mata kuliah Bahasa Inggris Profesi (BIP), yaitu bahasa Inggris khusus yang disajikan dalam perkuliahan pada mahasiswa MPW, STIPAR Triatma Jaya sesuai dengan bidang yang ditempuh dalam sebuah program studi, dalam hal ini yang digunakan dalam dunia Kepariwisataan. BIP juga merupakan salah satu mata kuliah yang dimuat dalam kurikulum Program Studi MPW di STIPAR Triatma Jaya. Mahasiswa juga dapat termotivasi untuk lebih tekun dalam pembelajaran Bahasa Inggris dengan penyajian MK BIP tersebut. Penyajian BIP juga dapat memotivasi mahasiswa untuk belajar lebih giat dan komprehensif terhadap bahasa Inggris, baik secara tulisan maupun lisan, mengingat begitu pentingnya peranan bahasa Inggris bagi mahasiswa MPW di STIPAR Triatma Jaya.

Salah satu keterampilan bahasa yang sangat dibutuhkan oleh mahasiswa MPW adalah Berbicara dalam bahasa Inggris yang baik dan efektif. Keterampilan ini dapat terbentuk dari penguasaan kosa kata-kosa kata yang berkaitan dengan dunia pariwisata, kemampuan menguasai genre yang terdapat dalam teks, seperti narative text, deskriptive text, report texs, recount texs, prosedure texs, review texs, dan explanation texs. Pemahaman genre teks ini dapat diperoleh dari kemampuan mahasiswa dalam keterampilan membaca pemahaman. Setelah mendapatkan genre dari setiap teks mahasiswa akan mampu berbicara secara efektif tentang sebuah objek pariwisata, bahkan kemampuan berbicara talks as transaction yaitu kemampuan mahasiswa MPW dalam menjual paket-paket tour kepada pelanggan domestik maupun manca negara.

$\begin{array}{ccc}\text { Berdasarkan hasil observasi } & \text { han } \\ \text { langsung yang dilakukan terhadap }\end{array}$ mahasiwa MPW ketika dilakukan tes awal dapat disampaikan bahwa penyampaian materi ajar yang dilakukan oleh dosen kurang efektif karena hanya dilakukan dengan metode ceramah. Hal ini disebabkan karena peran serta mahasiswa secara aktif belum maksimal. Bertolak dari kurikulum STIPAR Triatma Jaya, diketahui bahwa mahasiswa MPW Semester 4 telah mendapatkan matakuliah bahasa Inggris, yaitu (1) BIP 1, (2) BIP 2 dan pada saat penelitian sedang menempuh matakuliah BIP 3. Penyajian BIP 1 dan BIP 2 disajikan dalam 150 menit dalam 14 kali pertemuan dalam setiap semester. Berdasarkan kurikulum STIPAR Triatma Jaya penyajian BIP 1 dan 
BIP 2 harus dipadukan dalam penyajian teori dan praktik berbahasa Inggris dalam waktu penyajian.

Tes pertama yang disajikan kepada mahasiswa adalah multiple choice test sebanyak 20 soal. Tes ini mengandung evaluasi tentang menemukan struktur genre dari masing-masing teks dan menentukan jenis genre teks. Adapun soal-soal yang termasuk multiple choice test adalah :

Table 1. Contoh Soal-soal multiple choice dalam Pemahaman Genre Text Berbahasa Inggris

\begin{tabular}{|c|c|}
\hline No & Soal - Soal \\
\hline 1 & $\begin{array}{l}\text { In this case of other minor breakdown, which will immobile the tour } \\
\text { vehicle for some time, the tour guide should very politely ask his } \\
\text { participants to be patient. If a minor breakdown occur near a café or } \\
\text { restaurant, the tour guide should suggest that the participants wait there } \\
\text { while repair are made, talking refreshments at their own expense. } \\
\text { In the case of participants injured in a serious accident immediate } \\
\text { care must be taken of injuries, using first aid if needed, or possible. } \\
\text { Immediately an ambulance must be sent for, policemen must be } \\
\text { contacted, and participants must be conveyed to the nearest hospital } \\
\text { without delay } \\
\text { The text above is in form of: } \\
\text { a. Narative } \\
\text { b. Recount } \\
\text { c. Procedure } \\
\text { d. Descriptive }\end{array}$ \\
\hline 2 & $\begin{array}{l}\text { The village of Trunyan, lying on the bank of lake Batur, Kintamani, } \\
\text { is a village inhabitant by the aborigines of the Bali Age. These people } \\
\text { have special funeral customs and practice their own religion } \\
\text { Trunyan is derived from "taru menyan" ( the smell of fragrant } \\
\text { three of incense), the name of beautiful girl of his village who married } \\
\text { Dadonta, a God in Disguise. When she was left by her husband, she } \\
\text { promised to watch this village from the invisible world and this village } \\
\text { become prosperous. } \\
\text { Dadonta prohibited her to remarry. She promised not to do so, so } \\
\text { that she could meet him in heaven. After the death of taru menyan, the } \\
\text { people of this village created a huge image of Dadonta as their God, } \\
\text { and called him "Ratu Gede Pusering Jagat" ( His Majesti of the centre } \\
\text { of the world). The people of this village still worship this God until today. } \\
\text { The reorientations of the text could be found at paragraph: } \\
\text { a. Paragraph i } \\
\text { b. Paragraph } 2 \\
\text { c. Paragraph } 3 \\
\text { d. Paragraph } 1 \text { and } 3\end{array}$ \\
\hline
\end{tabular}


Tingkat kemampuan mahasiswa dalam mengidentifikasikan genre dari masing-masing teks adalah berbeda-beda. Hal ini dapat dilihat dari prosentase pemerolehan score dari mahasiswa berbeda-beda. Kemampuan dalam mengidentifikasi genre recount yang mendominasi yaitu sekitar 93.75\%. Kemudian diikuti oleh kemampuan mengidentifikasikan genre teks advertisement sebanyak 87.50. Sedangkan kemampuan mahasiswa dalam mengidentifikasikan genre teks descriptive, pada prosentase $68.75 \%$. Kemampuan mahasiswa dalam pemahaman genre procedur sebanyak 43.75 sedangkan dalam memahami dan mengidentifikasikan genre report sebanyak 56.25. Dari pemerolehan jumlah prosentasi dari setiap genre tersebut diatas maka dapat disimpulkan bahwa mahasiswa sudah mampu memahami genre recount, descriptive, report dan advertisement. Hal ini dapat dibuktikan dengan prosentase pemerolehan sebanyak $50 \%$ s/d $90 \%$.

Namun mahasiswa belum mampu mengidentifikasikan genre text prosedur. Hal ini dapat dilihat dari table diatas dimana hanya 7 orang mahasiswa atau sekitar $43.75 \%$ yang mampu mengidentfikasikan genre text tersebut.

Procedure text adalah sebuah text yang yang mengandung penjelasan, langkah-langkah dan cara-cara melakukan sesuatu. Struktur dalam teks procedure terdiri dari (1) aim : mengandung pemaran tujuan dari proses pembuatan sesuatu; (2) materials : mengandung barang dan BIP 2 yaitu penyajian materi Travel document. Materi travel document ini mengandung pembelajaran tentang guide order, guide report, tour escort report, VISA dan passport. Pembuatan guide repor dan tour escort report sangat berhubungan report text. Mahasiswa MPW masih tergolong mampu mengidentifikasi genre report text yaitu $56.25 \%$. Sehingga pusat perhatian dan pembelajaran genre text ini lebih besar benda yang digunakan dalam proses pembuatan dan (3) steps : mengandung proses dan langkah-langkah pembuatan sesuatu. Sedangkan report text didefinisikan sebagai sebuah teks yang mengandung informasi tentang terjadinya sesuatu hal. Memberikan gambaran umum tentang kejadian yang baru saja terjadi melalui pengamatan dan analisis yang sistematis merupakan tujuan umum dari report text. Terdapat 2 struktur dari report text yaitu: (1) general classification: berisi gambaran umum mengenai suatu kejadian, (2) description: berisi deskripsi dari kejadian yang ingin disampaikan.

Dalam pembelajaran MKK seperti praktik guiding mahasiswa selalu berhadapan dengan report text dan procedur text. Begitu juga dalam MK Travel Corespondence mahasiswa juga sering membaca report dan procedure text, misalnya mahasiswa harus membuat surat penawaran (letter of offer). Surat ini mengandung procedure text dan report. $\mathrm{Hal}$ ini dapat dijelaskan dengan dilengkapi surat penawaran ini dengan paket-paket tour, seperti (1) aim : mengandung pemaran tujuan dari paket tour yang ditawarkan; (2) materials : mengandung tujuan, waktu dan personil yang terlibat dan facilitas-faslitas yang digunakan dan terlibat dalam paket tour tersebut dan (3) steps : mengandung proses dan langkahlangkah pelaksanaan paket tour tersebut. Sedangkan report text, juga sudah dipelajari oleh mahasiswa. Salah satu MK yang menyajikan pembelajaran text tersebut adalah MK

pada pembelajaran procedure text yang sangat dibutuhkan mahasiswa MPW. Berdasarkan hasil test menulis karangan bebas namun masih dalam 5 jenis genre yaitu deskriptif, advertisement, procedures, report dan recount, diperoleh hasil bahwa mahasiswa MPW lebih menguasai genre teks deskrptif (100\%) dan advertisement (93.75\%). Penguasaan genre teks report maih 
menjadi perhatian khusus meskipun sudah mencapai $56.25 \%$ dimana mahasiswa masih termasuk dalam kategori mampu menulis jenis teks tersebut.

Kemampuan tertinggi mahasiswa dalam menulis karangan adalah menulis descriptive text, yaitu semua mahasiswa mampu menulis jenis karangan ini $(100 \%)$. Jenis karangan deskriptif adalah teks yang digunakan menggambarkan dan mendeskripsikan suatu objek atau tulisan dalam bahasa Inggris. Generik struktur dari descriptive text adalah (1)identification : penggambaran secara singkat mengenai objek yang akan diamati; (2) description : deskripsi mengenai objek yang kita amati. Jenis teks ini sering digunakan oleh mahasiswa dalam menceritakan dan menggambarkan sebuah objek wisata dan juga menceritakan sebuah fasilitasfasilitas pendukung dalam sebuah paket wisata seperti restoran, hotel, villa dan transfortation. Dan dengan penguasaan descriptive text tersebut dapat mendukung dan menguatkan kemampuan mahasiswa dalam kemampuan mahasiswa dalam keterampilan berbicara bahasa Inggris.

Kemampuan mahasiswa dalam menulis karangan bebas dengan genre advertisement menempati posisi kedua. Hal ini dibuktikan dengan pemerolehan 93.75\% atau sebanyak 15 mahasiswa

untuk mendapatkan pengalaman yang sama dengan penulis.

Kemampuan mahasiswa dalam menulis karangan bebas dengan genre procedure text menempati posisi yang keempat. Kemampuan mahasiswa dalam menulis teks ini termasuk dalam kategori mampu yaitu sebanyak 12 orang mahasiswa atau $75 \%$ mampu menulis jenis genre tersebut. Karangan yang dihasilkan lebih banyak bertemakan prosedur dalam menangani sebuah paket tour seperti prosedur memandu wisatawan dalam city tour dan mampu menulis jenis genre tersebut. Hal ini disebabkan oleh jenis genre ini dapat ditemukan di beberapa media sosial, papan pengumunan di kampus, dan pada pembelajaran pada MK Travel Correspondence. Jenis genre ini adalah merupakan sebuah teks yang berisis sebuah iklan yang memuat tentang sebuah produk, lowongan pekerjaan, dan jasa. Sebuah produk baik jasa maupun barang akan menjadi terkenal dan menarik adalah fungsi dari genre teks ini. Bahasa yang digunakan adalah bahasa yang bersifat persuasive. Kalimat yang digunakan sederhana, jelas, pendek, menggunakan slogan yang menarik dan persuasive.

Kemampuan mahasiswa dalam pemahaman genre recount menempati posisi ketiga yaitu sebanyak 14 ( $87.50 \%$ ) mahasiswa mampu menulis recount text. Hal ini dapat dibuktikan hasil karangan bebas yang telah dihasilkan oleh mahasiswa. Secara umum tema karangan recount text yang dihasilkan mahasiswa adalah tentang sebuah pengalaman traveling yang telah mereka lakukan. Dari tulisan tersebut dapat disimpulkan mahasiswa memiliki kemampuan menjual sebuah paket tour. Hal ini disebabkan karangan tentang pengalaman traveling mahasiswa sangat menarik dan membuat pembaca menjadi tertarik

prosedur khusus dari seorang tour guide. Hal ini disebabkan oleh pengalaman mahasiswa dalam menempuh MKK yang berhubungan dengan program studi mahasiswa yaitu Manajemen Kepariwisataan. Pengalaman praktik kerja industri di sebuah travel agent pada semester 3 juga mendukung hal tersebut.

Kemampuan menulis genre report texs menempati posisi terendah. Hal ini dibuktikan oleh sebagain kecil mahasiswa dapat menulis teks ini. Hanya 9 orang atau $56.25 \%$ mahasiswa 
yang mampu menulis karangan ini. 7 orang mahasiswa menghasilkan report text yang masih kurang dari ketentuan sebuah report texs. Kesalahan dari aspek ketepatan tata bahasa dan kosa didukung dan dipengaruhi oleh kemampuan membaca pemahaman dari mahasiswa. Pada tes tahap I mahasiswa telah menyelesaikan multiple choice test (tes terikat) dalam menentukan genre dari masing-masing teks dan menentukan struktur dari masing-masing teks. Dan sebelum dilakukan tes tahap ke 2 mahasiswa diberikan pembelajaran dalam 2 kali pertemuan tentang pemahaman genre dari 5 teks yang diujikan yaitu report text, recount text, descriptive text, procedures text, advertisement text. Pembelajaran lebih ditekankan pada penjelasan genre teks melalui keterampilan membaca pemahaman dan menulis salah salah satu dari 5 jenis genre teks yang tersebut diatas.

Berdasarkan observasi yang dilakukan penulis pada 2 hari penyajian pembelajaran tentang genre dari kelima teks tersebut dapat disimpulkan bahwa mahasiswa lebih tertarik pada pembelajaran genre teks yang tergolong advertisement text, descriptive text dan recount texs. Berdasarkan struktur dari sebuah teks, ketiga teks tersebut memiliki struktur yang lebih sederhana dan mudah dipahami serta sangat berhubungan dengan teks-teks yang diperoleh pada MKK yang harus ditempuh pada semester-semester sebelumnya. Berdasarkan hasil analisis data, dapat disimpulkan bahwa : Kemampuan mahasiswa MPW STIPAR Triatma Jaya Semester 4 dalam mengidentifikasikan genre teks (report text, recount text, descriptive text, procedures text, advertisement text ) adalah berbeda-beda. Kemampuan mengidentifikasi recount text sebesar $93.75 \%$, advertisement text sebanyak $87.50 \%$, descriptive text sebanyak $68.75 \%$, report text sebesar $56.25 \%$ dan kata yang masih mendominasi kesalahan mahasiswa.

Kemampuan mahasiswa dalam menulis 5 buah genre teks ini

procedures text sebesar $43.75 \%$ : (1)Jenis genre teks yang lebih mudah dipahami dan ditulis oleh mahasiswa MPW STIPAR Triatma Jaya adalah : (a) Descriptive text (100\%), advertisement text (93.75\%), dan recount text (87.50), (b) Pemerolehan score ini dipengaruhi oleh ketiga teks tersebut memiliki struktur yang lebih sederhana dan mudah dipahami serta sangat berhubungan dengan teks-teks yang diperoleh maka yang harus ditempuh pada semester-semester sebelumnya. (a) Peningkatan pemahaman descriptive text dan advetisement text disebabkan oleh penyajian pembelajaran tentang pemahaman genre teks melalui keterampilan membaca pemahaman (reading comprehension) yang disajikan dalam 2 kali pertemuan dan setiap pertemuan diakhiri dengan evaluasi yaitu tes membaca pemahaman dalam multiple choice test seperti yang telah dilakukan pada tes tahap I, (b) Peningkatan keterampilan membaca pemahaman berhubungan dengan pembelajaran keterampilan menulis. 


\section{DAFTAR RUJUKAN}

Adriani, Rina. 2011. Surat-surat bisnis berbahasa Inggris. Jakarta : PT. Grasindo

Halliday, M.A. K. 2004. An Introduction to functional Grammar. New York : Oxford University Press

Harrison Andrew. 1989. A Language Testing Handbook. London : Macmillan Publisher

Keith, Harding. 1994. High Season, English for Hotel and Tourist Industry. Oxford University Press. Melboune, Australia

Sinar, T. 2003. Analisis Wacana Berorientasi LFS. Medan : Program Pascasarjana USU

Udoyono, Bambang. 2001. English for Tourism. Yogjakarta : C.V. Andi OFFSET 